\title{
Aplikasi Akademik Untuk Pelayanan Wali Murid Berbasis SMS Gateway Pada SMP Negeri 2 Airgegas
}

\author{
Yudhi Rudini \\ Teknik informatika STMIK Atma Luhur \\ Jl.Jend Sudirman Selindung Lama Pangkalpinang \\ Kepulauan Bangka Belitung \\ yudhirudini@gmail.com
}

\author{
Ari Amir Alkodri \\ Teknik informatika STMIK Atma Luhur \\ Jl.Jend Sudirman Selindung Lama Pangkalpinang \\ Kepulauan Bangka Belitung \\ arie_a3@atmaluhur.ac.id
}

\begin{abstract}
During this very limited parents to monitor their children's academic activities ranging from school attendance, academic grades to violations committed by his son. That sometimes even surprise is when parents know their child's academic grades decreased and some are received letters of reprimand for their children's behavior. Thus the author makes an application for service-based SMS Gateway parents at SMP Negeri 2 Airgegas is expected able to assist parents in monitoring their learning activities at school, and help students to avoid reprimand the school due to absenteeism and decreased the value of their academic . Expected later this application can help the school, parents and students to improve student academic achievement in school
\end{abstract}

Keywords - tim marketing, smartphone, android

\section{PENDAhUluan}

Pada perkembangan teknologi saat ini banyak segala sesuatunya dilakukan serba canggih, mudah dan praktis. Manusia memerlukan komunikasi untuk saling bertukar ataupun mencari informasi dimana saja. Salah satu sistem komunikasi yang merupakan andalan bagi terselenggaranya integrasi sistem telekomunikasi secara global adalah dengan ditemukannya teknologi handphone yang sesuai dengan kebutuhan manusia, yaitu mampu berkomunikasi jarak jauh dimanapun mereka berada. Salah satu ciri mobile technology adalah untuk mendapatkan informasi ataupun pengaksesannya harus menggunakan cara yang mudah dan tidak mengganggu aktifitas mereka. Kemudian muncullah macam-macam fitur dari handphone, salah satunya adalah SMS (Short Message Service). Karena dengan fasilitas inilah kita dapat mengirimkan pesan kepada tujuan secara cepat, tepat dan dengan biaya yang murah. HP (Handphone) dengan fasilitas SMS adalah hal yang akan sangat berguna bila digunakan. Aplikasi sms gateway merupakan salah satu sarana untuk memenuhi kebutuhan saat ini yang menuntut segala sesuatunya dilakukan serba canggih, mudah dan praktis. Sehingga semakin banyaknya pengguna SMS seperti perusahaan, instansi, universitas maupun organisasi yang membuat layanan-layanan berbasis SMS, seperti informasi sekolah, mobile banking, pemesanan tiket, parking booking, pengisian KRS bahkan kuis-kuis yang ada di televisi sudah menggunakan fasilitas SMS. Pada sekolah-sekolahpun mulai ikut melakukan layanan berbasis SMS, Sehingga wali murid dapat mengetahui informasi akademik sekolah dengan menggunakan layanan aplikasi akademik berbasis SMS gateway. Dengan menggunakan aplikasi akademik berbasis SMS gateway diharapkan dapat membantu memajukan dunia pendidikan.

Pokok permasalahan pada SMP Negeri 2 Airgegas yang beralamat di Jl.Raya Desa Nyelanding adalah wali murid sering terlambat mendapatkan informasi mengenai nilai ujian tengah semester, nilai ujian akhir semester, nilai ekstrakulikuler, absensi, pelanggaran, jadwal ujian, dan informasi kegiatan yang dilakukan oleh pihak sekolah. Untuk penyampaian informasi akademik seperti informasi nilai, absensi, pelanggaran dan nilai ekstrakulikuler kepada para wali murid pihak sekolah masih menggunakan media kertas. permasalahan yang sering terjadi adalah tidak sampainya informasi akademik pelanggaran dan absensi kepada wali murid karena media yang digunakan masih menggunakan media kertas dan penyampaian informasi secara lisan. Salah satu alasan tidak sampainya informasi tersebut adalah karena siswa merasa takut untuk menyampaikan informasi absensi dan poin pelanggaran kepada wali murid.

Dari masalah-masalah tersebut maka perlu alternatif lain untuk mempermudah akses informasi diantaranya yaitu dengan metode membangun sebuah aplikasi akademik berbasis SMS Gateway yang membuat akses informasi lebih mudah didapat.

\section{LANDASAN TEORI}

\section{A. Definisi Analisa Rancangan}

Analisis adalah kegiatan berfikir untuk menguraikan suatu keseluruhan menjadi komponen sehingga dapat mengenal tanda-tanda komponen, hubungannya satu sama lain dan fungsi masing-masing dalam satu keseluruhan yang terpadu.

\section{B. Coding}

Menerjemahkan persyaratan logika dari pseudocode atau diagram alur ke dalam suatu bahasa pemrograman baik huruf, angka, dan simbol yang membentuk program. 


\section{Compiler}

adalah sebuah program komputer yang berguna untuk menerjemahkan program komputer yang ditulis dalam bahasa pemrograman tertentu menjadi program yang ditulis dalam bahasa pemrograman lain. Merupakan cara untuk pengkonversian program menjadi bahasa yang di mengerti oleh mesin. proses compile itu sendiri dilakukan secara interpreter dari baris awal program hingga baris akhir program, sehingga ekstensi java berubah menjadi class.

\section{Testing}

Pengujian perangkat lunak Menurut Standar ANSI/IEEE 1059: Proses menganalisa suatu entitas software untuk mendeteksi perbedaan antara kondisi yang ada dengan kondisi yang diinginkan (defect/errors/bugs) dan mengevaluasi fiturfitur dari entitas software. Pengujian perangkat lunak dapat dinyatakan sebagai proses validasi dan verifikasi bahwa sebuah program dapat memenuhi:

- Memenuhi kebutuhan (requirement) yang mendasari perancangan dan pengembangan perangkat lunak tersebut

- Perangkat lunak berjalan sesuai dengan yang diharapkan

- Dapat diterapkan menggunakan karakteristik yang sama

- Memenuhi kebutuhan semua pihak yang berkepentingan

\section{E. Implementasi}

Implementasi adalah proses untuk memastikan terlaksananya suatu kebijakan dan tercapainya kebijakan tersebut. Impelementasi juga dimaksudkan menyediakan sarana untuk membuat sesuatu dan memberikan hasil yang bersifat praktis terhadap sesama. Van Horn Dan Van Meter mengartikan Implementasi kebijakan sebagai : "tindakan-tindakan oleh individu publik dan swasta (atau kelompok) yang diarahkan pada prestasi tujuan yang ditetapkan dalam keputusan kebijakan sebelumnya". (Van Horn Dan Van Meter dalam Subarsono 2006 : 100).

\section{F. Short Message Service (SMS)}

Short Message Sevice (SMS) adalah salah satu fasilitas dari teknologi GSM yang memungkinkan mengirim dan menerima pesan singkat berupa text dari Mobile Station (MS). Layanan SMS juga memungkinkan pengiriman pesan dalam bentuk alphanumeric.

\section{G. Bahasa Pemrograman}

\section{1) Java}

Java adalah bahasa pemrograman yang berorientasi objek (Object Oriented Programming) dan dapat dijalankan pada beberapa plarform system operasi. Perkembangan Java tidak hanya berfokus pada satu sistem operasi, tetapi dikembangkan untuk berbagai sistem operasi dan bersifat open source.

2) $M y S Q L$

MySQL adalah multiuser database yang menggunakan bahasa structured query anguage (SQL). MySQL dalam operasi client-server melibatkan server daemon MySQL di sisi server dan berbagai macam program serta library yang berjalan di sisi client.

\section{3) Netbeans}

Netbeans sebagai IDE ditujukan untuk memudahkan pemrograman Java. Dalam Netbeans, pemrograman dilakukan berbasiskan visual dan event driven.

\section{4) $X A M P P$}

XAMPP adalah perangkat lunak bebas, yang mendukung banyak system operasi, merupakan kompilasi dari beberapa program. XAMPP merupakan tool yang menyediakan paket perangkat lunak ke dalam satu buah paket.

5) $S Q L$

SQL adalah sebuah konsep pengoperasian database, terutama untuk pemilihan atau seleksi dan pemasukan data, yang memungkinkan pengoperasian data dikerjakan dengan mudah secara otomatis. Kehandalan suatu sistem database (DBMS) dapat diketahui dari cara kerja Optimizer-nya dalam melakukan proses perintah-perintah SQL, yang dibuat oleh user maupun program-program aplikasinya.

\section{6) Sistem Kerja Usulan}

Sistem ini menggunakan Java dan MySQL Front sebagai database. Maka dari itu dibuat sebuah komputer server yang dapat terhubung dengan handphone sebagai operator dan terminal, kemudian komputer server tersebut diberikan aplikasi/program Receiver (penerima SMS) yang digunakan untuk mengambil instruksi yang diberi dari Media SMS tersebut.

\section{H. Teknologi GSM}

Teknologi komunikasi selular sebenarnya sudah berkembang dan banyak digunakan pada awal tahun 1980 an, diantaranya sistem C-NET yang dikembangkan di Jerman dan Portugal oleh Siemens, sistem RC-2000 yang dikembangkan di Perancis, sistem NMT yang dikembangkan di Belanda dan Skandinavia oleh Ericsson, serta sistem TACS yang beroperasi di Inggris.

\section{1) Arsitektur jaringan}

Secara bersama-sama, keseluruhan network element di atas akan membentuk sebuah PLMN (Public Land Mobile Network). Mobile Station (MS) merupakan perangkat yang digunakan oleh pengguna untuk melakukan pembicaraan. 
2) Operation and Support System (OSS)

Merupakan sub sistem jaringan GSM yang berfungsi sebagai pusat pengendalian. Berikut adalah Frekuensi pada 3 Operator Terbesar di Indonesia :

- Indosat : 890-900 Mhz (10 Mhz)

- Telkomsel : 900-907.5 Mhz (7.5 Mhz)

- Excelcomindo : 907.5- 915 Mhz (7.5 Mhz)

\section{Metode Penelitian}

\section{A. Teknik Pengumpulan Data}

1) Metode Kepustakaan

Metode ini dilakukan untuk mengumpulkan data dan informasi melalui buku-buku atau sumber bacaan lainnya serta beberapa situs internet dan dari pihak sekolah sendiri yang berkaitan dengan penyusunan skripsi dan aplikasi yang sedang dianalisa dan akan dibangun.

\section{2) Metode Wawancara}

Dengan cara melakukan wawancara dengan pihak yang melakukan pengelolaan data akademik siswa di SMPN 2 Airgegas untuk mengetahui permasalahan yang dihadapi dan mendiskusikan aplikasi yang diharapkan dapat memecahkan permasalahan tersebut.

\section{3) Metode Analisa Sistem}

Pengembangan berorientasi objek terdiri dari pengumpulan kebutuhan akan sistem dan menganalisa kebutuhan tersebut. Pada tahap ini, use case digunakan untuk membantu mengembangkan model yang dapat memberikan sebuah pemahaman yang lebih dari sistem yang akan dibangun.

\section{4) Metode Perancangan Sistem}

Pada tahap konstruksi, model selanjutnya dikembangkan lebih lanjut dan keseluruhan sistem dirancang dan diimplementasikan. Terdapat dua tahapan penting dalam proses konstruksi, yaitu desain dan implementasi.

\section{B. Use Case Diagram}

\section{1) Admin}

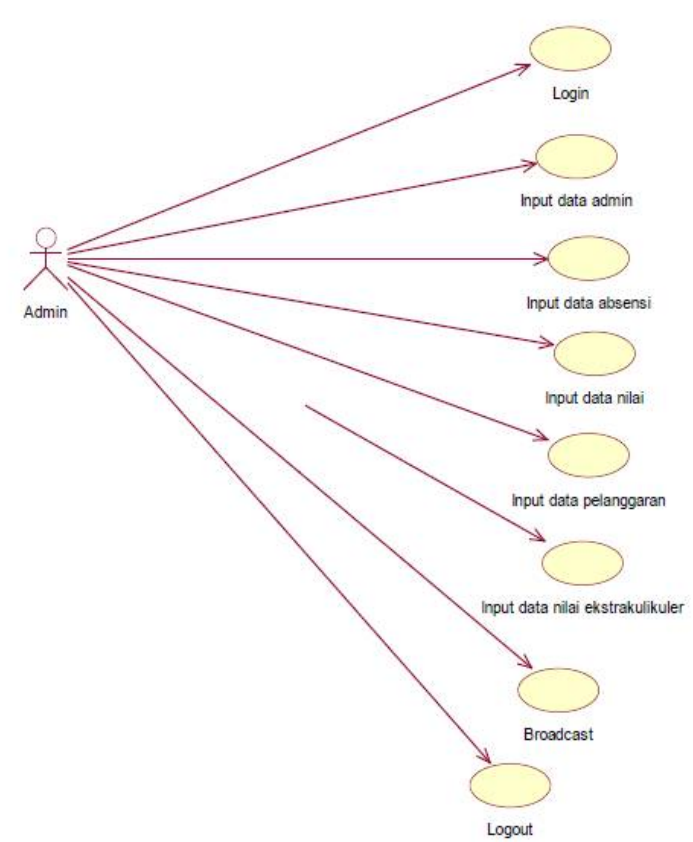

Gambar 1. Use Case Diagram Admin

2) Wali Murid

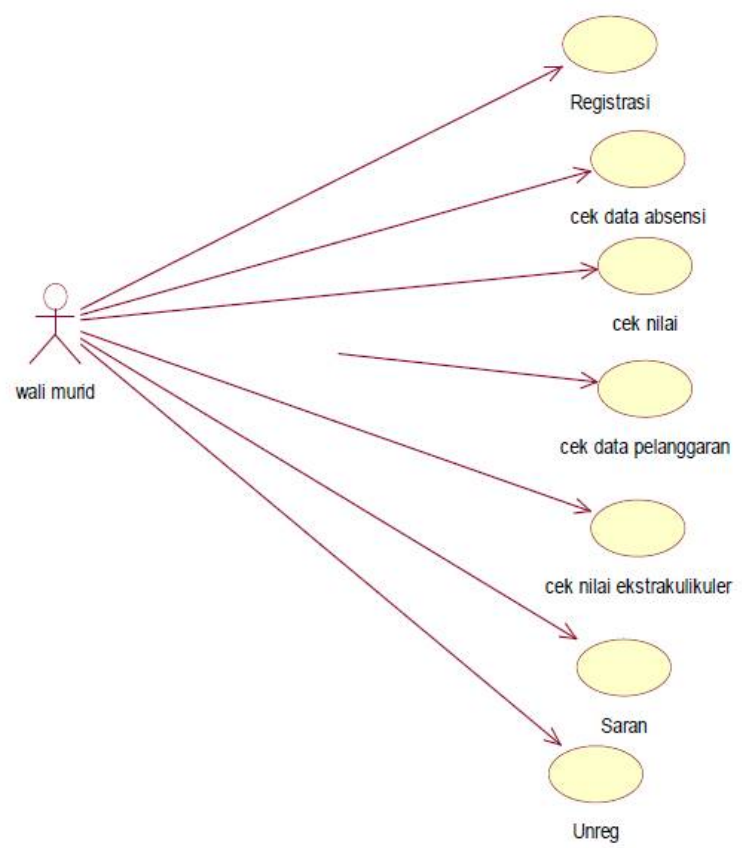

Gambar 2. Use Case Diagram Wali Murid 
C. Entity Relationship Diagram

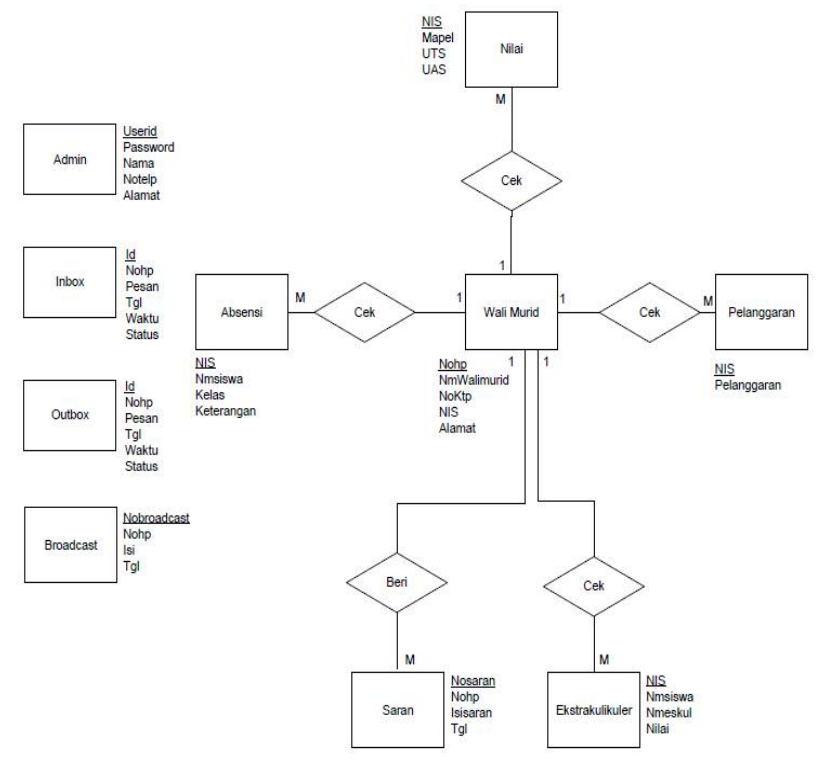

Gambar 3. ERD

D. Algroritma

\begin{tabular}{|c|c|}
\hline 1 & Tampikan Form Nilai \\
\hline 2 & Input Koda SMS Nilai , Nama Mapel, uts, uas \\
\hline 3 & Input Pilih \\
\hline 4 & If Pilih = Tambah Then \\
\hline 5 & Jalan Proses Tambah Data Nilai \\
\hline 6 & Kambali ke nomor 1 \\
\hline 7 & Else If $P$ ilih $=5$ impan Then \\
\hline 8 & Jalan Proses Simpan Data Nilai \\
\hline 9 & Kembali ke nomor 1 \\
\hline 10 & Else If Plih = Ubah Then \\
\hline 11 & Jalan Proses Ubah Data Nilai \\
\hline 12 & Kambali ke nomor 1 \\
\hline 13 & Else If Plilh = Refresh Then \\
\hline 14 & Jalan Proses Refresh Data Nilai \\
\hline 15 & Kembali ke nomor 1 \\
\hline 16 & Else If Pilih $=$ Tutup Then \\
\hline 17 & Kembali ke nomor 1 \\
\hline 18 & Else \\
\hline 19 & Kambali ke Menu Utama \\
\hline 20 & End If \\
\hline
\end{tabular}

Gambar 4. Algoritma Tambah, Simpan, Ubah, Hapus Data Nilai
E. Rancangan Alur Proses

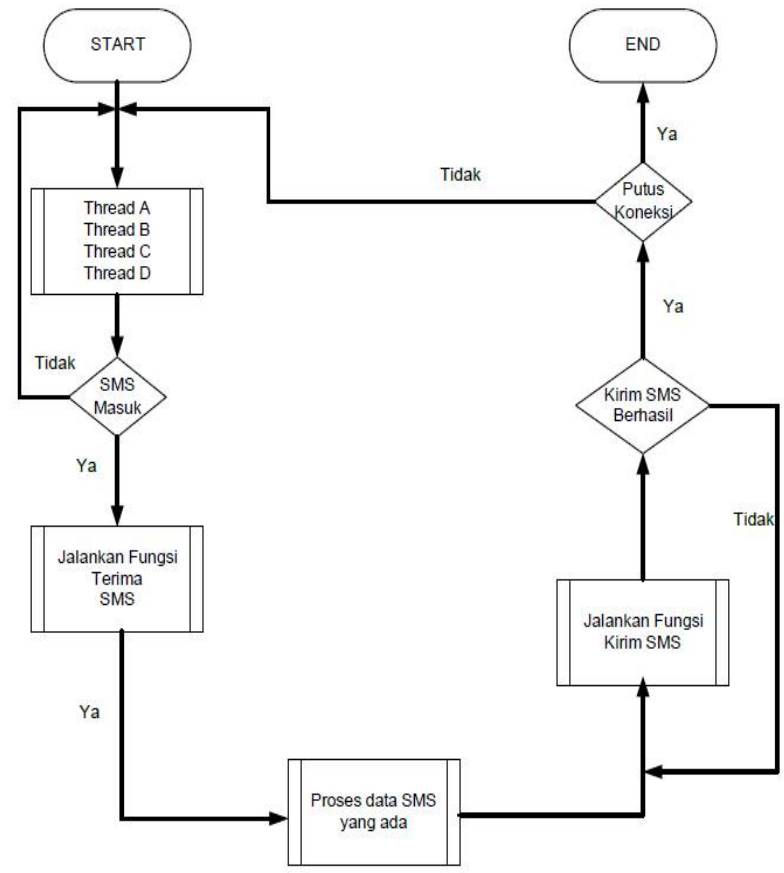

Gambar 5. Flowchart Sistem Kerja SMS

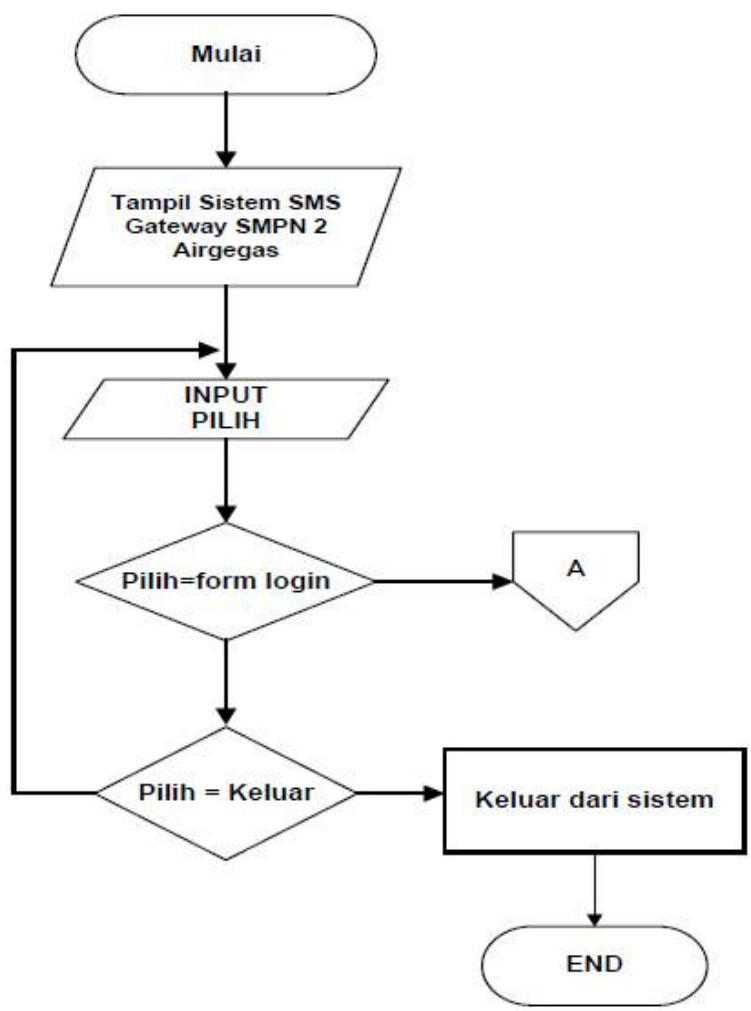

Gambar 6. Flowchart Awal 
IV. HASIL DAN PEMBAHASAN

\section{A. Tampilan Menu Utama}

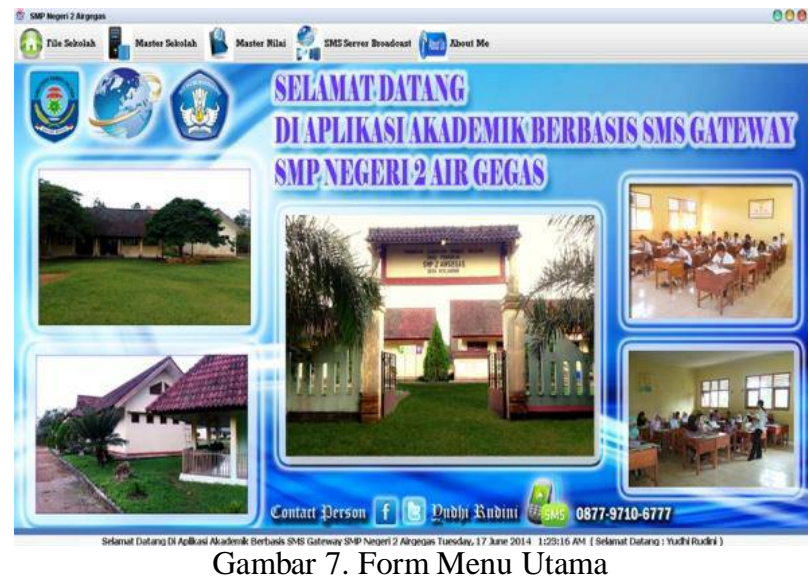

B. Tampilan Form Login

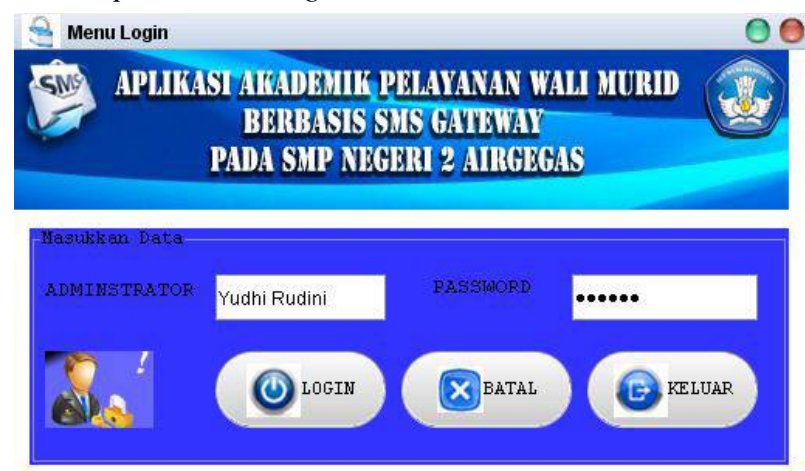

Gambar 8. Form Login

\section{Tampilan Form Nilai}

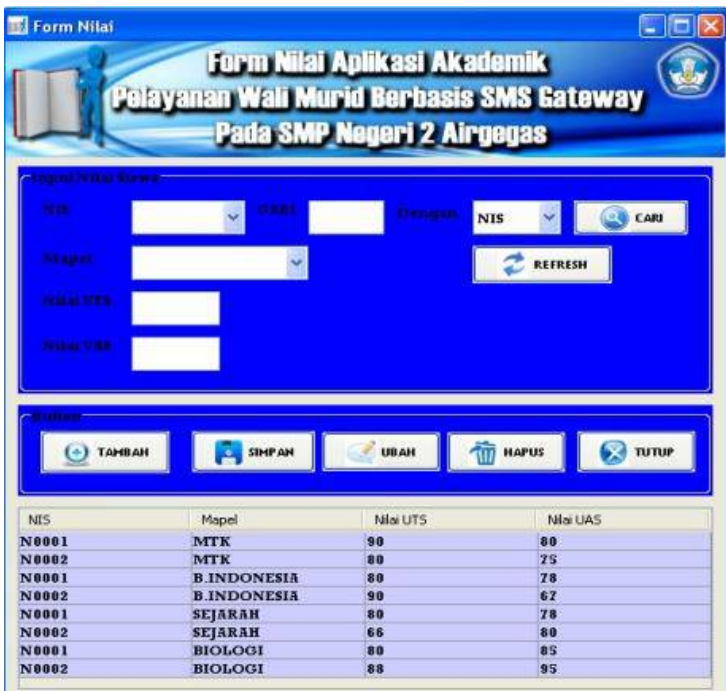

Gambar 9. Form Nilai
D. Tampilan Form Pelanggaran
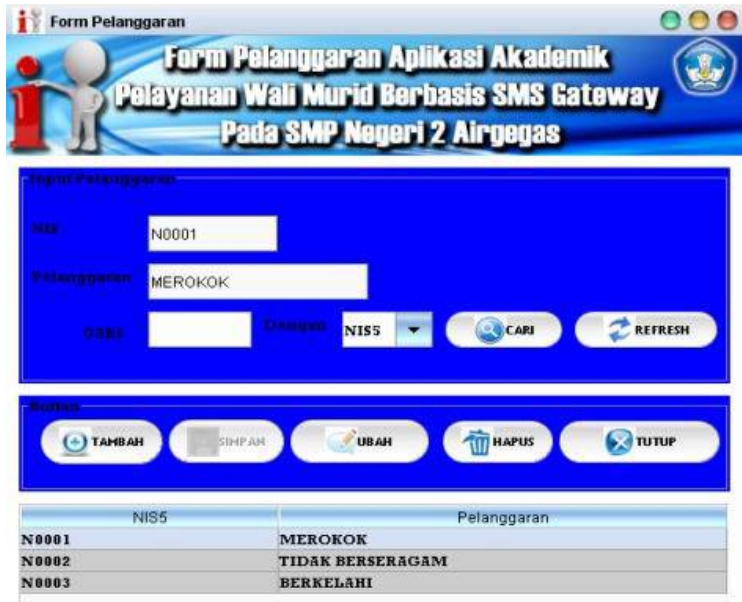

Gambar 10. Form Pelanggaran

E. Tampilan Form SMS Server

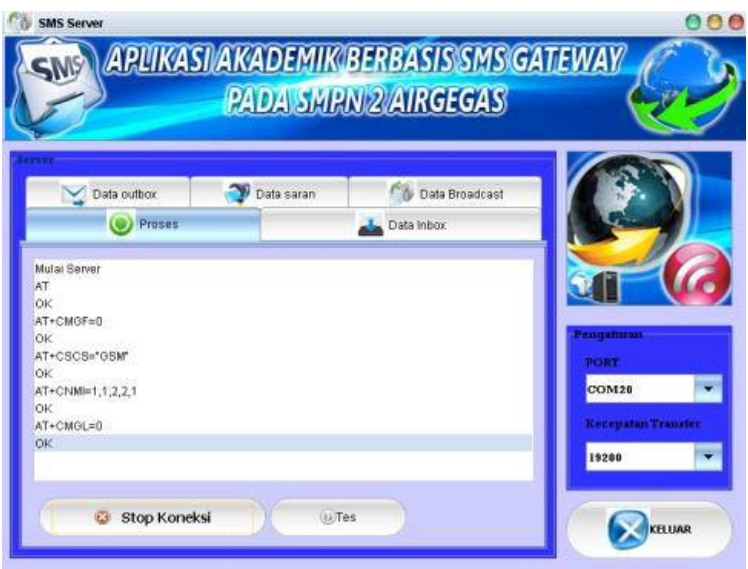

Gambar 11. Form SMS Server

\section{F. Tampilan Request HELP}

Request "HELP" untuk mengetahui informasi format SMS yang bisa dikirimkan ke server Aplikasi SMS Gateway Pelayanan wali murid pada SMPN 2 Airgegas, yang kemudian akan dibalas dengan pesan SMS yang berisi informasi format SMS untuk request.

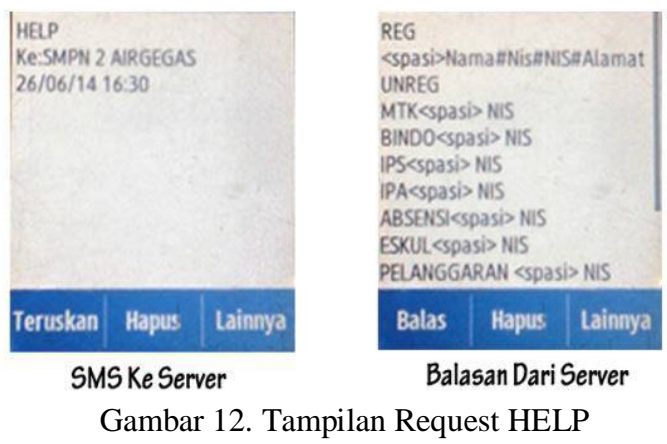




\section{G. Tampilan Request REG}

Request "REG" berfungsi untuk melakukan pendaftaran pada aplikasi SMS Gateway Pelayanan wali murid pada SMPN 2 Airgegas. Dengan Format Pesan yaitu : REG $<$ spasi $>$ NamaWaliMurid $<$ spasi $>$ NoKtp $<$ spasi $>$ NIS $<$ spasi $><$ A lamat>.

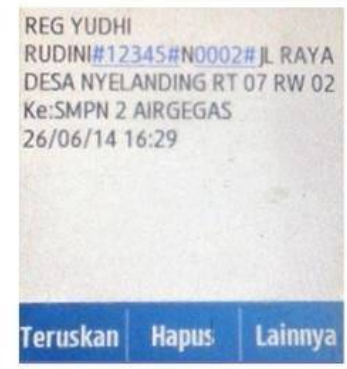

SMSKe Server

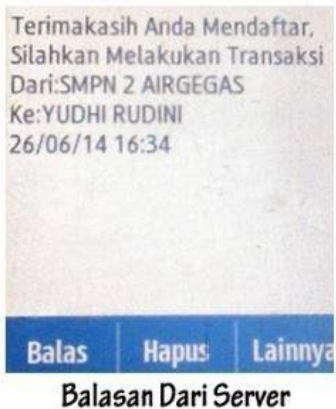

Gambar 13. Tampilan Request REG

\section{H. Request Nilai}

Request Nilai berfungsi untuk mengecek Nilai Mata Pelajaran.

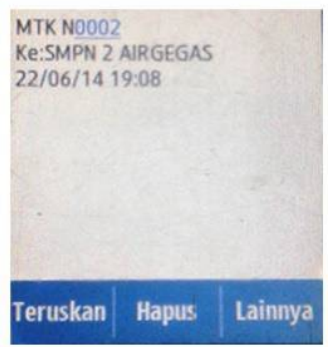

SMSKe Server

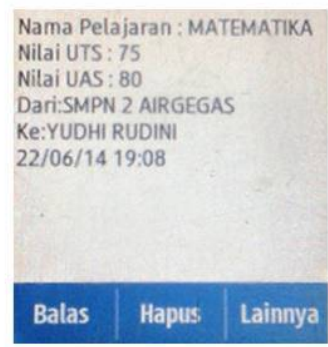

Balasan Dari Server
Gambar 14. Tampilan Request Nilai

\section{Format Pengiriman SMS}

Tabel 1. Format Request Pengiriman SMS

\begin{tabular}{|c|c|}
\hline Format SMS & Keterangan \\
\hline HELP & Informasi Menu Request \\
\hline $\begin{array}{l}\text { REG<spasi }>\text { Nama\#Noktp\#Nis\# } \\
\text { Alamat }\end{array}$ & Pendaftaran Wali Murid \\
\hline \multicolumn{2}{|c|}{ FORMAT SMS NILAI } \\
\hline MTK<spasi $>$ NIS & Request Nilai MTK \\
\hline $\mathrm{BINDO}<$ spasi $>$ NIS & Request Nilai B.Indonesia \\
\hline IPS $<$ spasi $>$ NIS & Request Nilai IPS \\
\hline IPA $<$ spasi $>$ NIS & Request Nilai IPA \\
\hline PELANGGARAN<spasi>NIS & Request Pelanggaran \\
\hline ABSEN <spasi> NIS & Request Absen \\
\hline ESKUL<spasi> NIS & Request Ekstrakulikuler \\
\hline UPDATE<spasi>NoKtp & Request Update No.HP \\
\hline SARAN<spasi>isi saran & Pemeberian Saran \\
\hline UNREG & $\begin{array}{l}\text { Keluar Sistem Sms } \\
\text { Gateway }\end{array}$ \\
\hline
\end{tabular}

\section{PENUTUP}

\section{A. Kesimpulan}

Dari hasil analisa terhadap masalah dan aplikasi yang dikembangkan maka dapat ditarik beberapa kesimpulan, antara lain :

- Dengan adanya aplikasi berbasis SMS ini, dapat memudahkan wali murid dalam pengecekan nilai, absensi, pelanggaran da nilai ekstrakulikuler anaknya

- Dengan Penerapan dan pemanfaatan aplikasi akademik sms gateway ini bisa menjadi solusi alternatif untuk meringankan pekerjaan bidang kesiswaan dan wali kelas yang selama ini masih memanfaatkan media kertas sebagai input data akademik.

- Pelayanan terhadap kebutuhan informasi data akademik khususnya wali murid menjadi efektif dan cepat.

\section{B. Saran}

Berikut ini diuraikan juga saran yang mungkin bisa dijadikan pertimbangan dalam pengembangan sistem selanjutnya, antara lain:

- Spesifikasi perangkat keras harus sesuai dengan kebutuhan program sehingga aplikasi bekerja dengan benar.

- Tanpa adanya perawatan dan pengawasan dari pihak yang bertanggung jawab dalam pemeliharan sistem, maka sistem tidak akan berjalan dengan baik dan lancar.

- Informasi yang diakses melalui SMS masih terbatas bagi pengguna yang mungkin belum memiliki handphone.

\section{DAFTAR PUSTAKA}

[1] Alkodri, Ari Amir. , 2013, Pemanfaatan Teknologi Handphone dari SMS Sebagai SMS Gateway Server, J2Me Mobile, Android Berbasis GIS, Mikrokontroler ON OFF. Pangkalpinang

[2] Cahyono, Setiyo., 2006, Panduan Praktis Pemrograman Database Menggunakan MySQL dan JAVA. Bandung

[3] Deitel Harvey. M. And Paul. J. Deitel, 2003, Java How To Program, Fifth Edition. New Jersey : Prentice Hall

[4] Gunawan Ferry. Membuat Aplikasi SMS Gateway Server dan Client Dengan Java dan PHP. Elex Media Komputindo. Jakarta.2003

[5] Jugiyanto H.M, Analisa dan Design Sistem Informasi Pendekatan Terstruktur teori dan Praktek Aplikasi Bisnis.2006

[6] Komputer Wahana. Pengembangan Aplikasi Sistem Akademik Berbasis SMS dengan Java. Salemba Infotek. Jakarta. 2005

[7] Martine, Inge. 2003. Microsoft SQL Server 2000. Jakarta : PT. Elex Media Komputido

[8] Purnama Rangsang, Tuntunan Pemrograman Java Jilid 2. Tim Prestasi Pustaka. Surabaya. 2003

[9] Purnama Rangsang, Tuntunan Pemrograman Java Jilid 3. Tim Prestasi Pustaka. Surabaya. 2003

[10] Mulyana Y.B, S.Kom, Trik Membangun Situs Menggunakan PHP dan MYSQL. Elex Media Komputindo. Jakarta. 2003 
[11] Suherman.A, G. Hariman.Pemodelan Sistem Informasi Berorientasi Objek Dengan UML, edisipertama. Yogyakarta :GrahaIlmu, 2002

[12] Wahana Komputer. Tim Penelitian dan Pengembangan, 2005, Pengembangan Aplikasi Sistem Informasi Akademik Berbasis SMS dengan JAVA, Edisi Pertama. Jakarta : Salemba Infotek.

[13] Wicaksono, Ady., 2002, Dasar-Dasar Pemrograman Java 2. Jakarta : PT.Elex Media Komputindo.

[14] Wikipedia Indonesia. 2013. "Global System Communications". http://id.wikipedia.org/wiki/Global_System_for_Mobile_Communicatio $\mathrm{ns} /$

[15] Diakses pada tanggal 24 Mei 2014

[16] Safaat, Nasruddin, Pemrograman Aplikasi Mobile Smartphone Dan Tablet PC Berbasis Android, 2012. 